\title{
Kasvinviljelyn energiankulutuksen mittaaminen
}

Tapani Jokiniemi ${ }^{\text {1) }}$, Jukka Ahokas ${ }^{2)}$

${ }^{1)}$ HY, maataloustieteiden laitos, Koetilantie 3, 00014 Helsingin yliopisto, tapani.jokiniemi@ helsinki.fi

${ }^{2)}$ HY, maataloustieteiden laitos, Koetilantie 3,00014 Helsingin yliopisto, jukka.ahokas@helsinki.fi

\section{Tiivistelmä}

Maatalouden energian kulutukseen on alettu kiinnittää entistä enemmän huomiota osana yleisiä energiasäästötavoitteita. Kasvinviljelyssä energian säästö on helpointa aloittaa tuotannon suorista energiapanoksista, jotka muodostuvat pääasiassa koneiden ja viljankuivauksen polttoaineena käytetystä polttoöljystä. Jotta energiaa voidaan säästää, on tiedettävä kuinka paljon sitä kuluu tarkasteltavan systeemin sisällä ja miten kulutus jakaantuu eri osasysteemeihin. Lisäksi energiankulutus on pystyttävä ilmoittamaan sellaisissa yksiköissä, että kulutuksen vertailu vaihtoehtoisten prosessien tai menetelmien välillä on mahdollista.

Peltotöissä polttoaineen kulutus vaihtelee paljon maalajien ja olosuhteiden vaihdellessa. Tässä tutkimuksessa kehitettiin ja testattiin yksinkertaista ja edullista menetelmää polttoaineen kulutuksen määrittämiseen laajamittaisesti käytännön olosuhteissa. Mittaus tehtiin koneiden oman polttoainemittarin anturin jännitesignaalin, GPS-paikannuksen sekä manuaalisen kirjanpidon avulla. Mittauslaitteisto on helppoa asentaa ja se sopii lähes mihin tahansa työkoneeseen. Anturin jännitesignaali tallennettiin tiedonkeruulaitteelle ja signaalin muutoksista laskettiin paikkatiedon ja kirjanpidon avulla polttoaineenkulutus eri työvaiheille. Kulutus ilmoitettiin yksikössä 1/ha, joka on useimmissa töissä käyttökelpoisin mittayksikkö. Mittauksia tehtiin useimmista tavanomaisista viljan- ja nurmenviljelyn konetöistä.

Tutkimuksen johtopäätöksenä todettiin tämän kaltaisen mittaustavan olevan käyttökelpoinen menetelmä maataloustöiden polttoaineenkulutuksen määrittämiseen tietyin varauksin. Luotettavien tulosten saaminen edellyttää, että peltolohkot ovat suhteellisen isoja ja työ on riittävän yhtäjaksoista. Menetelmän tarkoituksena ei ole ilmoittaa tarkkoja kulutuslukemia, vaan sitä voidaan käyttää maatalouden keskimääräisten energiankulutuslukemien laskemiseen. Lisäksi sen avulla pystytään löytämään prosesseista kohtia, jotka vaativat tarkempaa analysointia. Polttoaineenkulutuksen lisäksi menetelmää voidaan käyttää peltotöiden työhyötysuhteen määrittämiseen.

Asiasanat: energian säästö, maatalous, maatalouskoneet, polttoaineen kulutus, kulutuksen mittaaminen, työhyötysuhde 


\section{Johdanto}

Fossiilisten energiavarojen hupeneminen sekä niiden käytöstä aiheutuvat ilmastovaikutuksen ovat johtaneet energiansäästötavoitteisiin useimmilla tuotannonaloilla. Myös maatalouden energiankäyttöön on alettu kiinnittää entistä enemmän huomiota osana yleisiä säästötavoitteita. Maatalouden energian käyttöä on alettu ohjailla aluksi vapaaehtoisuuteen perustuvien energia-ohjelmien avulla. Esimerkkinä vapaaehtoisesta energiasuunnittelusta on vuonna 2010 käynnistynyt maatilojen energiaohjelma, jonka tavoitteena on vähentää maatalouden kokonaisenergian kulutusta $9 \%$ vuoteen 2016 mennessä (Motiva 2011).

Kasvinviljelyssä suurin yksittäinen energiapanos on lannoitteiden valmistukseen käytetty epäsuora energia. Mikkolan ja Ahokkaan (2009) mukaan sen osuus on yli $50 \%$ maatalouden kokonaisenergiankulutuksesta. Lannoituksen satovaste on kuitenkin hyvä, eli kasvit hyödyntävät käytetyn energian hyvällä hyötysuhteella. Jos nykyiset satotasot halutaan säilyttää, ei keinolannoitukselle ole tällä hetkellä olemassa varteenotettavia vaihtoehtoja.

Energian säästötoimet kannattaa aloittaa niistä kohteista, joihin on helpoin vaikuttaa. Maatalouden kasvinviljelyssä näitä ovat peltotöiden ja viljan kuivauksen suorat energiapanokset, eli koneiden ja viljankuivurin polttoaineena käytetty kevyt polttoöljy. Käytettävällä teknologialla, työmenetelmien valinnalla sekä koneiden käyttötavalla voidaan saada aikaan tilatasolla merkittäviäkin säästöjä energian kulutuksessa. Säästöjen laajempaa merkitystä pohdittaessa on hyvä pitää mielessä, että maatalouden osuus Suomen vuotuisesta polttoaineiden kulutuksesta on noin 2 \% (MTT 2010). Koska energia todennäköisesti tulee tulevaisuudessa kallistumaan fossiilisten energiavarojen huvetessa, tulee energiankulutus kuitenkin nousemaan entistä merkittävämpään asemaan myös yksittäisen tilan kannattavuustekijänä.

Jotta energian käyttöä pystytään vähentämään, on tiedettävä kuinka paljon sitä kuluu tarkasteltavan systeemin sisällä ja miten kulutus jakautuu systeemin eri osien välillä. Lisäksi energiankulutus on pystyttävä ilmoittamaan sellaisina toiminnallisina yksikköinä, jotka mahdollistavat vertailun erilaisten vaihtoehtoisten prosessien ja menetelmien välillä. Tässä tutkimuksessa kehitettiin ja testattiin yksinkertaista ja edullista menetelmää, jolla pystytään määrittämään työkoneiden polttoaineen kulutus litroina peltohehtaaria kohti. Tämä on useimmissa kasvintuotannon konetöissä käyttökelpoisin yksikkö, sillä se suhteuttaa käytetyn energian parhaiten saavutettuun työtulokseen. Lisäksi se vähentää olosuhteiden vaikutusta tuloksiin; jos energiankäyttö mitattaisiin esimerkiksi tuotettua massayksikköä kohti, saataisiin hyvän ja huonon satovuoden välillä aivan erilaiset tulokset, vaikka kaikki olisi periaatteessa tehty "oikein".

Tutkimus tehtiin osana ENPOS-hanketta, jonka tavoitteena on selvittää maatalouden energiankäyttöä sekä löytää mahdollisuuksia energiansäästöön.

\section{Aineisto ja menetelmät}

Tutkimuksen tavoitteena oli kehittää ja testata yksinkertaista ja edullista menetelmää kasvinviljelyn työkoneiden polttoaineen kulutuksen määrittämiseen yksikössä 1/ha. Yksittäisen työvaiheen osalta polttoaineen kulutus voidaan mitata suhteellisen tarkasti ja helposti virtausmittauksen ja tunnetun pinta-alan avulla. Mittauslaitteiston asentaminen vaatii kuitenkin muutoksia koneen polttoainejärjestelmään, aiheuttaen polttoainevuotojen riskin ja lisäten työmäärää sekä kustannuksia. Koska olosuhteet pellolla vaihtelevat huomattavasti, on aineiston oltava riittävän iso, jotta saadaan työn ominaiskulutusta hyvin kuvaavia keskimääräisiä lukuja.

Tässä tutkimuksessa polttoaineen kulutusta mitattiin koneiden oman polttoainemittarin jännitesignaalin avulla, mikä mahdollisti vaivattoman ja edullisen tiedonkeruun koko kasvukauden ajalta. Koneiden sijainti ja liikkeet pelloilla tallennettiin yksinkertaisen GPS-henkilöpaikantimen avulla. Lisäksi koneiden kuljettajat pitivät päiväkirjaa siitä, millä peltolohkoilla on milloinkin työskennelty ja mitä on tehty. Kirjanpitoon merkittiin myös koneiden tankkausmäärät. Polttoaineen kulutuslukemat olisi mahdollista laskea myös suoraan kirjanpidosta, mutta ongelmana on tankatun polttoainemäärän kohdentaminen tietylle pinta-alalle. Tämän tutkimuksen mittaustuloksista voidaan eristää ajanjakso, jolloin on liikuttu tietyllä lohkolla tai lohkoilla, ja laskea hehtaarikohtainen kulutus lohkojen pintaalojen perusteella.

Polttoainemittarin anturi muodostuu yleensä kellukkeesta, joka on kytketty säätövastukseen. Kelluke liikkuu akselillaan polttoaineen pinnan tason mukaan, muuttaen vastuksen resistanssia. Tämä näkyy anturilta tulevan jännitesignaalin muutoksina. Jännitesignaalin tasoa vastaavan polttoainemää- 
rän selvittämiseksi luotiin jokaiselle koneelle kalibrointikäyrä. Polttoainesäiliö pumpattiin ensin tyhjäksi, jonka jälkeen se täytettiin 10 litran erissä. Anturin jännitesignaali tallennettiin samanaikaisesti. Tällä tavoin saadusta käyrästä muodostettiin jokaista konetta varten yhtälö, jonka avulla säiliössä oleva polttoainemäärä voitiin laskea anturin jännitesignaalin perusteella. Esimerkki kalibrointikäyrästä on esitetty kuvassa 1.

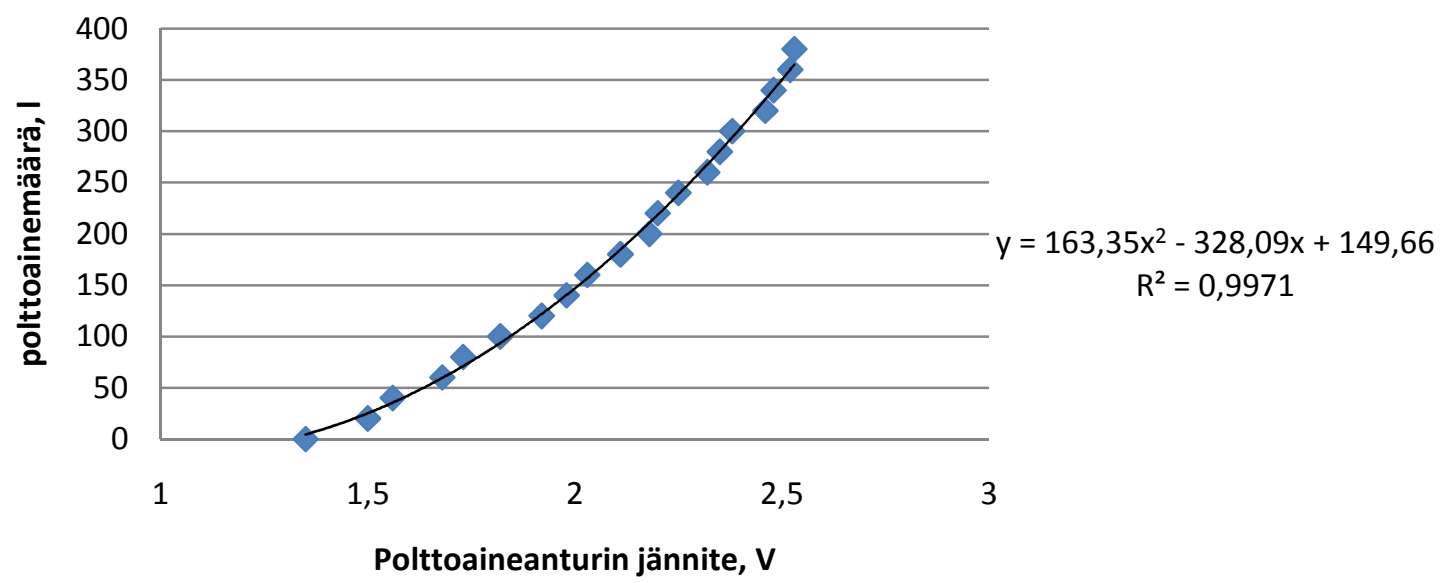

Kuva 1. Polttoaineanturin jännitteen riippuvuus tankissa olevasta polttoainemäärästä leikkuupuimurissa.

Polttoainemittarin anturin jännitesignaali tallennettiin jänniteloggerilla, joka asennettiin sopivaan paikkaan koneen polttoainesäiliön lähelle ja liitettiin anturilta lähteviin johtimiin. Koneiden liikkeiden tallentamiseen käytetty GPS-paikannin sijoitettiin sisälle traktorin ohjaamoon. Sekä anturin jännitesignaali että paikkatiedot tallennettiin 30 sekunnin välein. Paikannuksesta saatuja tietoja täydennettiin ajopäiväkirjan perusteella, ja hehtaarikohtaisen polttoaineen kulutuksen laskemiseen käytettiin lohkojen tarkkoja pinta-aloja tilan lohkokorteista. Mittausten päätteeksi tiedonkeruulaitteiden keräämä data ladattiin tietokoneelle analysointia varten. Tietojen analysointi tehtiin Exceltaulukkolaskentaohjelmalla. Siirtoajot tilakeskuksesta pellolle ja lohkolta toiselle jätettiin huomiotta, sillä niiden merkitys suhteessa pellolla kulutettuun polttoainemäärään on pieni välimatkojen ollessa suurimmillaan muutamia kilometrejä. Kuvassa 2 on mittauslaitteisto asennettuna Valtra N140 traktoriin.
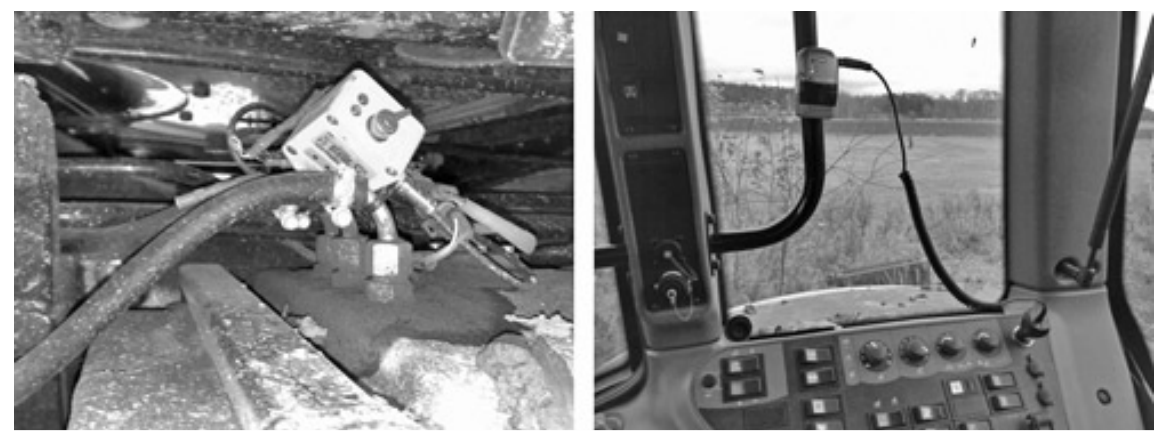

Kuva 2. Yksinkertainen ja edullinen laitteisto polttoaineen kulutuksen määrittämiseen Valtra N140 -traktoriin.

Mittauksia tehtiin kahdella tilalla: yhdistettyä kasvinviljelyä ja lypsykarjataloutta harrastavalla tilalla Uudellamaalla vuosina 2010 ja 2011 sekä sianlihan tuotantoon keskittyneellä tilalla Satakunnassa vuonna 2011. Vallitseva maalaji molemmilla tutkimukseen kuuluneilla tiloilla on hietasavi. Mittausten piiriin kuuluivat useimmat tavanomaiset peltotyöt: äestys, kylvö, leikkuupuinti, kyntö, nurmen niitto ja paalaus, noukinvaunulla ajo sekä lannan levitys. 


\section{Tulokset ja niiden tarkastelu}

Tulosten perusteella polttoaineen kulutuksen mittaaminen koneiden oman polttoaineanturin jännitesignaalin perusteella osoittautui toimivaksi menetelmäksi. Kirjapitoon merkittyjen tankkausten perusteella voidaan laskea, että tulokset ovat hyvin oikean suuntaisia. Kuvassa 3 on esimerkki tallennetusta polttoaineanturin jännitesignaalista. Taulukossa 1 on esitetty mittaustuloksista lasketut keskimääräiset polttoaineen kulutuslukemat hehtaaria kohti mitatuille työvaiheille. Tulokset on laskettu lohkokorttien ilmoittamista pinta-aloista, joten lukemat on laskettu todellisen pinta-alan mukaan. Toinen tapa kulutuksen laskemiseen on käyttää keskimääräistä ajonopeutta sekä kertoa se kullakin lohkolla vietetyllä ajalla sekä käytetyllä työleveydellä. Tällä tavalla laskettuna saadaan teoreettinen pinta-ala, joka ei ota huomioon päistekäännöksiä ja päällekkäin ajoa.

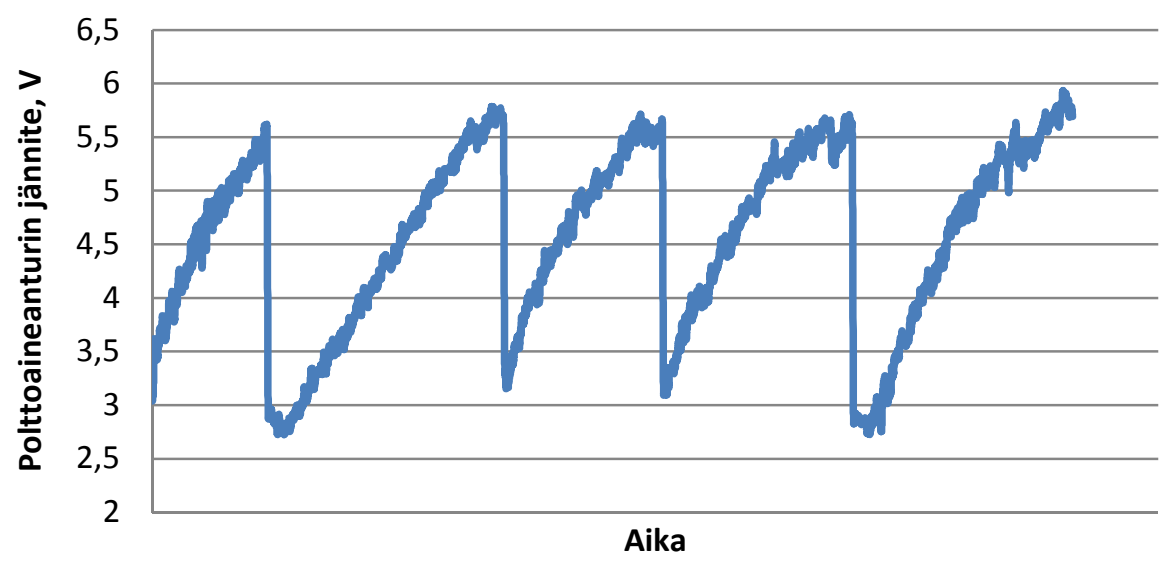

Kuva 3. Kylvötyöstä tallennettu polttoaineanturin jännitesignaali.

\begin{tabular}{lccc} 
Työvaihe & Tila 1 2010 & Tila 1 2011 & Tila 2 2011 \\
\hline Aäestys & 8,1 & - & 7,1 \\
Kylvö & 5,3 & - & 7,5 \\
Leikkuupuinti & 10,6 & 8,9 & 9,4 \\
Kyntö & - & - & 16,3 \\
Lietteen levitys* & - & - & 3,6 \\
Niitto & 4,1 & - & - \\
Paalaus & 5 & - & - \\
Noukinvaunu & - & 14,5 & - \\
\hline
\end{tabular}

*Letkulevitin

Taulukko 1. Mittaustuloksista laskettuja keskimääräisiä polttoaineen kulutuslukemia, 1/ha.

Tulokset poikkeavat jonkin verran Mikkolan ja Ahokkaan (2009) eri lähteistä keräämistä keskimääräisistä arvoista. Maalajien, olosuhteiden ja satojen vaihtelu vaikuttaa luonnollisesti tuloksiin ja samoja arvoja eri sijainneilla ja vuosilla ei voida odottaa saatavan. Myös erilaisista työmenetelmistä aiheutuu eroja. Esimerkiksi kylvön tapauksessa suhteellisen suurta eroa tilojen välillä selittää erilainen kylvömuokkaustapa. Kummallakin tilalla kylvö tehdään esimuokkaimella varustetulla kiekkovannaskoneella, mutta tilalla 1 kaikki pellot äestetään ennen kylvöä, jolloin kylvökoneen esimuokkainta ei tarvita kylvön yhteydessä. Tilalla 2 puolestaan osa kylvöistä tehdään syksyllä kynnetylle äestetylle pellolle, osa keväällä sängestä muokatulle sekä osa syksyllä sänkimuokatulle pellolle. Kylvökoneen vetovastus on tällöin keskimäärin isompi ja myös esimuokkainta käytetään. 
Leikkuupuinnissa vaihtelua polttoaineen kulutukseen syntyy sadon määrästä sekä erilaisista olosuhteista. Tutkimuksen tiloilla leikkuupuimurit olivat myös erimerkkisiä ja kokoluokaltaan erilaisia, mutta tämän vaikutusta energian kulutukseen ei näiden tulosten perusteella voida arvioida. Kynnön osalta mitattu kulutuslukema on suhteellisen alhainen, esimerkiksi Mikkola ja Ahokas (2009) esittivät kynnölle arvoa 25 1/ha. Myös tätä voidaan selittää olosuhteiden ja maalajien vaikutuksella. Tilalla 2, josta kynnön polttoaineenkulutus mitattiin, käytettiin kyntöä perusmuokkausmenetelmänä lähinnä kevyimmillä maalajeilla. Lisäksi myös kyntösyvyydellä on suuri vaikutus kulutukseen.

Nurmenviljelytöiden osalta ero eri rehunkorjuutapojen polttoaineenkulutuksessa on huomiota herättävän suuri. Noukinvanulla kulutus oli lähes 15 l/ha, kun paalauksen kulutus oli vain 5 l/ha. Noukinvaunun käyttöön sisältyy luonnollisesti myös rehun siirto varastoon, kun paalit puolestaan jäävät paalaamisen jäljiltä pellolle. Tilalla 1, jossa noukinvaunumittauksia tehtiin, sijaitsevat peltolohkot kuitenkin rehuvaraston välittömässä läheisyydessä. Kokonaisenergiankulutusta laskettaessa myös paalaukseen käytettävien verkkojen ja muovien valmistusenergia on otettava huomioon. Ero rehunkorjuutapojen energiankulutuksessa on joka tapauksessa niin suuri, että tarkempi mittaaminen olisi perusteltua.

Päistekäännösten ja päällekkäin ajon takia kaikki pellolla vietetty työaika ei koskaan ole tehollista työaikaa. Tutkimuksessa käytettyjen mittausmenetelmien avulla voidaan määrittää myös työhyötysuhde, eli tehollisen työajan suhde kokonaistyöaikaan. Tämä saadaan laskemalla paikannustiedoista teoreettinen käsitelty pinta-ala ajonopeuden, ajan sekä työleveyden avulla ja jakamalla tämä luku lohkon tai lohkojen todellisella pinta-alalla. Taulukossa 2 on laskettu muutama esimerkki työhyötysuhteista. Hyötysuhde on käytännössä laskettavissa sellaisille töille, joissa pellon koko pinta-ala käsitellään yhteen kertaan.

\begin{tabular}{lc} 
Työvaihe & Työhyötysuhde, \% \\
\hline Kylvö & 76 \\
Leikkuupuinti & 76 \\
Niitto & 87 \\
\hline
\end{tabular}

Taulukko 2. Mittaustuloksista laskettuja työhyötysuhteita eri töissä.

\section{Johtopäätökset}

Tutkimuksen johtopäätöksenä voidaan todeta polttoaineen kulutuksen mittaamisen koneiden oman polttoaineanturin jännitesignaalin perusteella olevan toimiva ja käyttökelpoinen menetelmä tietyin varauksin. Tulosten laskemiseksi menetelmä vaatii rinnalleen kirjanpidon pelloilla tehdyistä töistä, josta käy ilmi myös lohkojen pinta-alat. Vaihtoehtoisesti riittää myös tutkitun tilan lohkokartat, joiden avulla lohkojen pinta-alat voidaan yhdistää koneiden polttoaineen kulutuksesta ja sijainnista sekä nopeudesta kerättyihin tietoihin. Viimeksi mainittu tapa on kuitenkin huomattavasti työläämpi, eikä edullisten paikannuslaitteiden toiminta ollut tämän tutkimuksen perusteella kovinkaan luotettavaa.

Jotta menetelmällä saavutetaan luotettavia tuloksia, on peltolohkojen oltava kohtalaisen isoja sekä työn riittävän yhtäjaksoista. Jos koneilla tehdään mitattavien töiden välillä muita töitä, vaikeutuu tulosten laskeminen huomattavasti.

Menetelmä on kohtalaisen vaivaton ja edullinen tapa keskimääräisten kulutuslukujen keräämiseen käytännön olosuhteissa. Mittaustulosten analysointi ja kulutuslukemien laskeminen vaatii kuitenkin melko paljon työtä. Tuloksia voidaan käyttää kasvinviljelyn keskimääräisen energiankäytön laskemiseen. Lisäksi niiden avulla voidaan löytää prosesseista kohtia, jotka vaativat tarkempaa analysointia tai mittaamista. Mittausjärjestelmä on myös helposti asennettavissa lähes mihin tahansa traktoriin tai työkoneeseen. 


\section{Kirjallisuus:}

Mikkola, H. \& Ahokas, J. 2009. Energy ratios in Finnish agricultural production. Agricultural and food science 18: 332-346.

Motiva 2011. [Viitattu 29.11.2011] Saatavana www-muodossa: <URL:

http://www.energiatehokkuussopimukset.fi/fi/sopimusalat/maatilat/maatilojen_energiaohjelma/>

MTT 2010. Luonnonvarapuntari. [Viitattu 8.10.2010] Saatavana www-muodossa: <URL:

https://portal.mtt.fi/portal/page/portal/Luonnonvarapuntari/Ymp\%E4rist\%F61/Ilmastonmuutos/Energian\%20k\% E4ytt\%F6> 